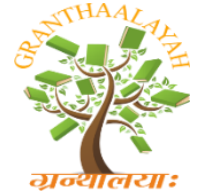

INTERNATIONAL JOURNAL OF RESEARCH GRANTHAALAYAH A knowledge Repository

RAST - 17

\title{
INFLUENCE OF CARBON BASED ELECTRODES ON THE PERFORMANCE OF THE MICROBIAL FUEL CELL
}

\author{
Omkar S Powar ${ }^{1}$, Lakshminarayana Bhatta K. G ${ }^{2}$, Raghavendra Prasad H. D ${ }^{1}$, Krishna \\ Venkatesh ${ }^{2}$, A.V. Raghu ${ }^{1}$ \\ ${ }^{1}$ Centre for Emerging Technologies, Jain Global Campus, Jain University, Jakkasandra, \\ Ramanagara 562 112, India \\ ${ }^{2}$ Centre for Incubation, Innovation, Research and Consultancy, Jyothy Institute of Technology, \\ India
}

DOI: https://doi.org/10.29121/granthaalayah.v5.i4RAST.2017.3296

\begin{abstract}
In this study electricity generation was evaluated in a two chambered microbial fuel cell. Performance of microbial fuel cells using two bacteria, Klebsiella pneumoniae and Bacillus coagulans and using three different electrodes namely graphite blocks, carbon cloth and graphite sheet was studied. The device was operated under anaerobic condition in the anode chamber and parameters were recorded for a period of 48 hours. The performance of MFC was analyzed by the measurement of open circuit voltage, polarization curves, impedance curves and cyclic voltammetry. Among different combinations of electrode tested, carbon cloth electrode produced high power density $(80 \mathrm{~mW} / \mathrm{m} 2)$. Graphite block gave much high power compared to sheet. Finally, performance was compared with Shewanella putrefaciens. The current study explores the applicability of carbon electrode for MFC applications.
\end{abstract}

Keywords: Microbial Fuel Cell; Open Circuit Voltage; Salt Bridge; Power Density; Electrode.

Cite This Article: Omkar S Powar, Lakshminarayana Bhatta K. G, Raghavendra Prasad H. D, Krishna Venkatesh, and A.V. Raghu. (2017). "INFLUENCE OF CARBON BASED ELECTRODES ON THE PERFORMANCE OF THE MICROBIAL FUEL CELL." International Journal of Research - Granthaalayah, 5(4) RAST, 7-16. https://doi.org/10.29121/granthaalayah.v5.i4RAST.2017.3296.

\section{Introduction}

Climate change due to anthropogenic emission of greenhouse gases (GHGs) and energy insecurity in the face of depleting fossil fuel reserves along with increasing demand and rise in prices have compelled the mankind to explore alternative renewable sources of fuels. In this direction, solar, biomass, wind, geothermal, and nuclear energies are some of the renewable energy sources identified to aid in the mitigation of global warming. To facilitate the effective 
[Powar et. al., Vol.5 (Iss.4: RAST), April, 2017]

ICV (Index Copernicus Value) 2015: 71.21

Recent Advances in Science \& Technology
ISSN- 2350-0530(O), ISSN- 2394-3629(P)

IF: 4.321 (CosmosImpactFactor), 2.532 (I2OR)

InfoBase Index IBI Factor 3.86

use of these resources, energy usage patterns and infrastructures have to be modified to develop energy saving technologies [1]. However, no single energy solution is sufficient to overcome the energy crisis. Off late, microbial fuel cell (MFC) has been identified as an alternative source of energy as they produce electricity without undergoing combustion [2]. These MFC's are seen as a promising technology for applications in energy generation and waste water treatment. In the recent years, there has been a great deal of interest in the production of bioelectricity using microbial fuel cells. MFC's find their potential applications in Electricity production from a variety of substrates such as waste water treatment, renewable biomass, in waste-water treatment, minimum amount of solid waste is generated from the process and the produced electricity is used for aerating the sludge [3]. Further in bio-hydrogen production involves the application of a small additional voltage for the evolution of hydrogen at the cathode. Moreover, MFCs are advantageous over other technologies by direct conversion of substrate to electricity, operating at low temperature and using in locations lacking electrical infrastructures [4]. Hence, a greater interest is given to studies based on MFCs that are identified as the future source of energy.

Microbial fuel cell is a device which converts chemical energy to electrical energy with the help of bacteria as a biocatalyst [5]. Electrons produced by bacteria utilizing the substrates are transferred to the anode and are allowed to flow to the cathode under a load. Electrons are combined with protons in the cathode that is diffused from the anode through a separator and forms water [6]. As a common source, bacteria are used for the conversion of organic matter to electricity. The power density and columbic efficiency of MFC is affected by the specific type of bacteria used. There are three ways in which bacteria transfers electrons to the anode: (1) direct transfer of electrons, which requires direct contact between the microbial cell membrane and the anode electrode; (2) using mediators produced by the bacteria; bacteria produces their own mediators and the system operates at high level of activity; (3) using exogenous mediators, they are potassium ferric cyanide, thionine, or neutral red $[7,8]$.

One of the crucial factors that determine the performance of MFC is the efficiency of the electrode. Various materials have been used as electrodes in the form of carbon such as plates, rods, granules, felt, cloth, paper, fiber and foams. Carbon has been widely used as an electrode material due to various properties such as low residual current, long term stability, excellent biocompatibility, high electrical conductivity, relatively high chemical stability, high corrosion resistance, low density thermal expansion and low cost [9].

Here, carbon is used as an electrode material for bio-electrochemical studies. In this study, the performance of two chambered MFC was evaluated using two different bacteria and three different electrodes namely carbon cloth, graphite sheet and graphite block. Two different bacteria that were used in the experiment were Klebsiella pneumoniae and Bacillus coagulans. The two microorganisms were isolated from a) Lake Sediments (Klebsiella pneumoniae) from Yediyur Lake, Bangalore b) Waste water and sludge (Bacillus coagulans) from Cubbon park sewage plant, Bangalore. Electrochemical techniques like Linear Sweep Voltammetry, A.C. Impedance Spectroscopy and Cyclic Voltammetry have been used to investigate the performance of MFC. Finally, the comparison of its performance is done using Shewanella putrefaciens as a reference which is common in most of the literature reports. 
2. Materials and Methods

\subsection{Set-Up}

The two chambered assembly consisted of plexi-glass elements that were bolted together. It consists of four end plates and two chambers held together by screws, nuts and wing nuts. The total volume of anode and cathode chambers was $700 \mathrm{ml}$, where both the chambers shared equal capacity. Salt Bridge was used to separate the two chambers $(4 \mathrm{~cm}$ length and $6 \mathrm{~cm}$ diameter). Salt bridge was prepared using sodium chloride (10\%) containing agar (3\%) in 100ml distilled water [10]. The solution was first subjected to heat for blending, which resulted in a clear solution. The same was poured into MFC salt bridge part and was solidified. Salt bridge was sealed with rubber gaskets on both sides to prevent liquid from leaking from one compartment to the other. The electrodes were graphite sheet (total accessible geometric surface area $1.3 \times 10$ $\left.3 \mathrm{~m}^{2}\right)$, graphite block $\left(3.38 \times 10-3 \mathrm{~m}^{2}\right)$ and carbon cloth $\left(30 \times 10-3 \mathrm{~m}^{2}\right)$. Copper wires were attached to each electrode and sealed using electric tape. The MFC was sterilized using ethanol (70\%) and irradiated with UV for $30 \mathrm{~min}$. Once fully assembled, leakage test was carried out. Silicone sealant was used to fix the leakage. Upon passing the leak test, the MFC was kept ready for inoculation.

\subsection{Culture and Medium}

Two different bacteria used in the experiment were Klebsiella pneumoniae and Bacillus coagulans. The two microorganisms were isolated from a) Lake Sediments (Klebsiella pneumoniae) from Yediyur Lake, Bangalore b) Waste water and sludge (Bacillus coagulans) from Cubbon park sewage plant, Bangalore. Standard enrichment technique was adopted for isolation of electrogenic bacterial strain. Isolated colonies were streaked repeatedly for getting pure culture and further identified by using $16 \mathrm{~S}$ rDNA sequencing technique. The two isolates Klebsiella pneumoniae and Bacillus coagulans were given the names as NMSB and SSA.

The anolyte had the following media components (g/L): Glucose (20), Asparagine (5), Yeast Extract (0.5), Peptone (0.5), $\mathrm{KH}_{2} \mathrm{PO}_{4}(0.8), \mathrm{K}_{2} \mathrm{HPO}_{4}$ (3) and $\mathrm{KCl}(0.2)$. The catholyte consists of phosphate buffer solution $100 \mathrm{mM}$ and potassium ferricyanide $50 \mathrm{mM}$. The anolyte was inoculated by $1 \mathrm{ml}$ of culture and was sealed using sealant to maintain an anaerobic condition. The cathode was continuously exposed to air. The test conditions were carried out at $\mathrm{pH} 7.0$ and temperature $28{ }^{\circ} \mathrm{C}$. The tests were monitored for a period of 48 hours.

\subsection{Electrochemical Techniques}

For all electrochemical measurements, $\mathrm{CH}$ Instrument (Model 600E) was used. It is a computerized general purpose potentiostat / galvanostat.

\subsection{Polarization Curves}

The potentiostat was operated in a two electrode setup to obtain polarization curves. In the twoelectrode setup, the working electrode connector is connected to the cathode and both the counter electrode and reference electrode connectors were connected to the anode. Polarization curves 
were obtained by linear sweep voltammetry (LSV). The scan rate of LSV was set to $0.1 \mathrm{mV} / \mathrm{s}$ with cathode as working electrode [11].

\subsection{Electrochemical Impedance Spectroscopy (EIS)}

Electrochemical impedance spectroscopy was performed with cathode as the working and anode as the counter and reference electrode. Impedance measurements were carried out at the open circuit voltage (OCV) over a frequency range of 105 to $0.1 \mathrm{~Hz}$ with sinusoidal perturbation of 5 $\mathrm{mV}$ amplitude. From the impedance data, Nyquist plots were drawn showing the real part of the impedance on the $\mathrm{x}$-axis and the imaginary part on the $\mathrm{y}$-axis. The plot consists of a semicircle and a linear portion. The distance between the first intersection and the second intersection is the sum (internal resistance) of the charge transfer and the diffusion resistances $[5,12]$.

\subsection{Cyclic Voltammetry (CV)}

Cyclic voltammetry was performed for determining the electrochemical activity of microbial strains. CV was carried out using a conventional three-electrode electrochemical cell of $20 \mathrm{ml}$ capacity. $\mathrm{CV}$ of the bacterial cell suspension was obtained using a potentiostat. A glassy carbon working electrode, platinum counter electrode and $\mathrm{Ag} / \mathrm{AgCl}$ reference electrode were used in the electrochemical cell. Measurements were carried out at $28^{\circ} \mathrm{C}$ under anaerobic conditions at the scanning rate of $25 \mathrm{mV} / \mathrm{s}$ using a potential range of $-800 \mathrm{mV}$ to $+800 \mathrm{mV}$ [13].

\subsection{Calculations}

The Chemical Oxygen Demand (COD) was measured using standard methods prescribed in the literature. Power densities were calculated using $\mathrm{P}=\left(\mathrm{V}^{*} \mathrm{I}\right) / \mathrm{A}$. This was calculated from geometrical surface area of the anode A, Current I and measured voltage V. Coulombic efficiency was calculated as:

Coulombic efficiency $=$ Coulombs recovered $/$ Total coulombs in substrate

Coulombic efficiency $=\frac{\mathrm{M}_{\mathrm{s}} * \mathrm{I}_{\mathrm{b}}}{\mathrm{F} * \mathrm{~b} * \Delta \mathrm{C} * \mathrm{~V}_{\mathrm{AN}}}$

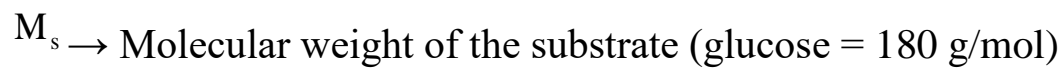

$\mathrm{I} \rightarrow$ Current obtained (A)

$\mathrm{t}_{\mathrm{b}} \rightarrow$ Time period over which the current is measured

$\mathrm{F} \rightarrow$ Faraday's constant $(96,500 \mathrm{C} / \mathrm{mol}$ of electrons)

$\mathrm{b} \rightarrow$ Number of mol of electrons produced per mol of substrate (glucose $b=24$ )

$\Delta \mathrm{C} \rightarrow$ Difference in the influent and effluent COD

$\mathrm{V}_{\mathrm{AN}} \rightarrow$ Volume of liquid in the anode compartment 


\section{Results and Discussions}

\subsection{Open Circuit Voltage (OCV)}

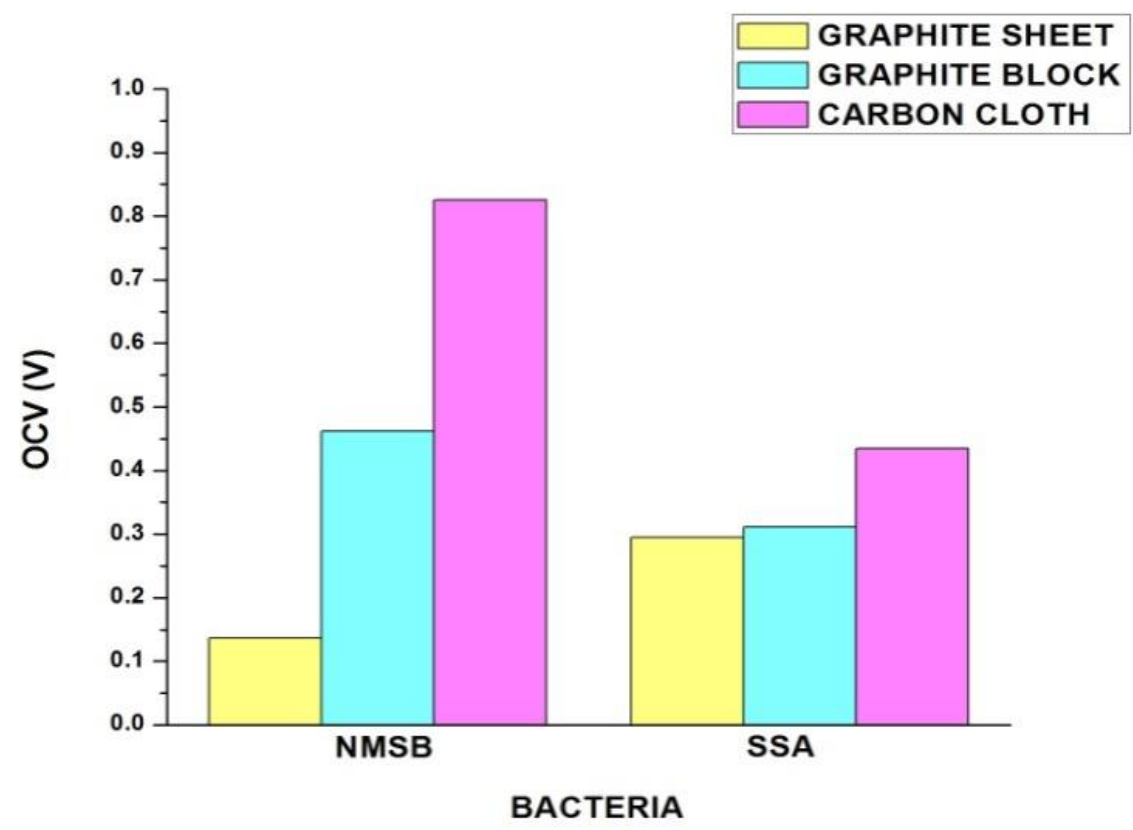

Figure 1: Maximum OCV of NMSB and SSA bacteria with different electrodes

The OCV was monitored for a period of 48 hours as the power production was limited. This may be due to increased dissolved oxygen, that might have inhabited bacterial growth and also due to nutrient limitation. Using NMSB bacteria, the highest value of OCV was found to be $0.854 \mathrm{~V}$ obtained with carbon cloth. OCV with graphite block and sheet was found to be $0.462 \mathrm{~V}$ and $0.1369 \mathrm{~V}$ respectively. Using SSA bacteria, the highest value of OCV was obtained with carbon cloth $0.434 \mathrm{~V}$. Similarly, OCV was found to be $0.3113 \mathrm{~V}$ and $0.2949 \mathrm{~V}$ with graphite block and sheet respectively.

Due to the transfer and adsorption of charged species at the interface between electrode and electrolyte, electrode potential appears. The more negative the anode potential, the higher the OCV. NMSB bacteria produced more electrons than SSA making the anode more negative and increasing the $\mathrm{OCV}$.

Better performance of carbon cloth material was confirmed from the cathode polarization data. Carbon cloth had a cathode potential in the range of 0.4-0.6 V (Ag/AgCl reference electrode). But the cathode potentials for graphite block and sheet were found to be in the range of 0.2-0.4 $\mathrm{V}$. 


\subsection{Potentiodynamic Polarization}
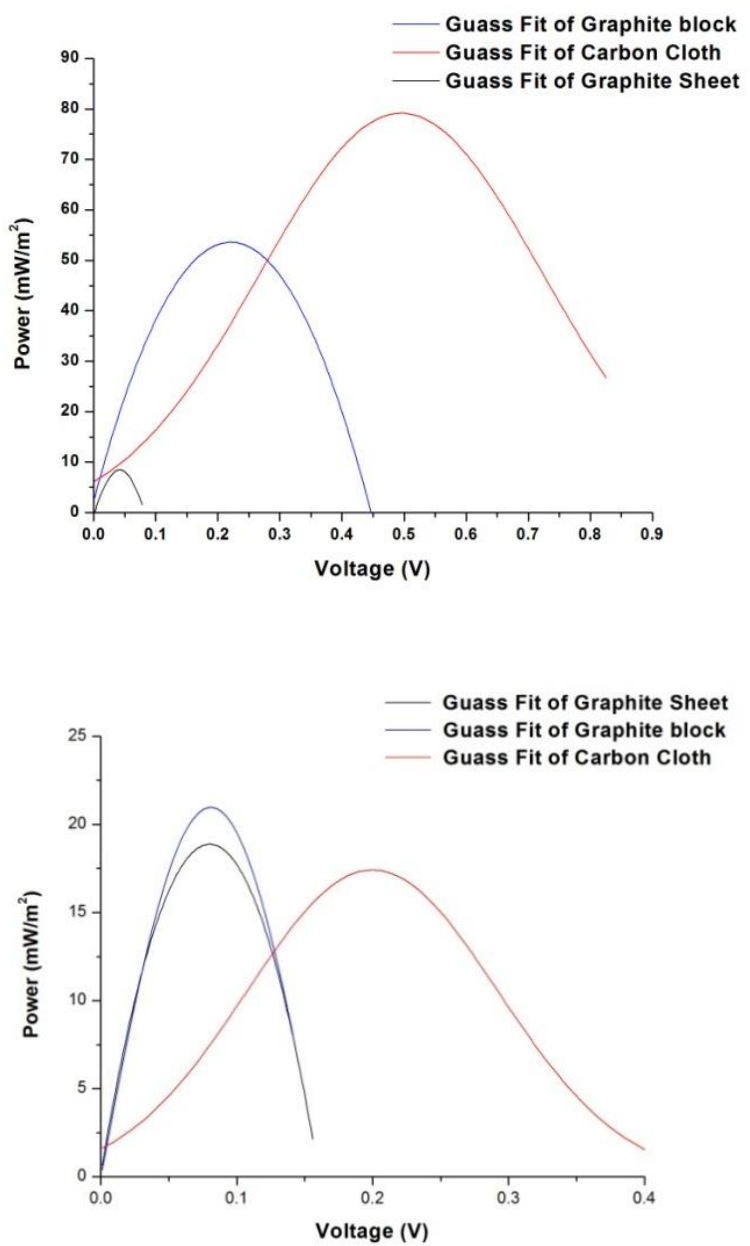

Figure 2: Polarization curves of NMSB and SSA bacteria with different electrodes

The characteristics of electricity generation were examined by polarization curves. Figure.2. shows the nonlinear curve fit of polarization curves obtained using Guass method. The coefficient of determination (r2) for graphite bock, carbon cloth and graphite sheet was 0.99699, 0.93692 and 0.98832 respectively with NMSB bacteria and for SSA bacteria it was found to be 0.94836, 0.9726 and 0.9909 . The maximum power levels determined from power curves derived from NMSB bacteria using carbon cloth, graphite block and graphite sheet were $80 \mathrm{~mW} / \mathrm{m}^{2}, 54$ $\mathrm{mW} / \mathrm{m}^{2}$ and $8.42 \mathrm{~mW} / \mathrm{m}^{2}$ with a columbic efficiency of $22.35 \%, 3.18 \%$ and $0.36 \%$ and COD of $522 \mathrm{mg} / \mathrm{L}$. The average power densities obtained were $30 \mathrm{~mW} / \mathrm{m}^{2}, 14 \mathrm{~mW} / \mathrm{m}^{2}$ and $1 \mathrm{~mW} / \mathrm{m}^{2}$ using carbon cloth, graphite block and graphite sheet respectively.

Similarly, using SSA bacteria maximum power levels obtained using carbon cloth, graphite block and graphite sheet were $20 \mathrm{~mW} / \mathrm{m}^{2}, 21 \mathrm{~mW} / \mathrm{m}^{2}$ and $19 \mathrm{~mW} / \mathrm{m}^{2}$ with a columbic efficiency of $23.30 \%, 4.093 \%$ and $2.73 \%$ and COD of $405 \mathrm{mg} / \mathrm{L}$. The average power densities obtained were $13 \mathrm{~mW} / \mathrm{m}^{2}, 8 \mathrm{~mW} / \mathrm{m}^{2}$ and $7 \mathrm{~mW} / \mathrm{m}^{2}$ using carbon cloth, graphite block and graphite sheet respectively. 
Using carbon cloth, power output was higher than graphite block and sheet. This is due to the affinity of bacteria towards specific electrode because of a high physical contact between the cells and the electrode. Carbon cloth is more flexible and porous compared to graphite sheet and block. Graphite block had a rough surface while, graphite sheet is not porous and provides lesser power per geometric (projected) surface area. Porous structure of carbon cloth provides more surfaces for the colonization and faster biofilm formation of the bacteria which increases the output power. The power output decreased with sheet due to the smooth surface that offered lesser surface for the formation of bio-film.

\subsection{Electrochemical impedance spectroscopy (EIS)}
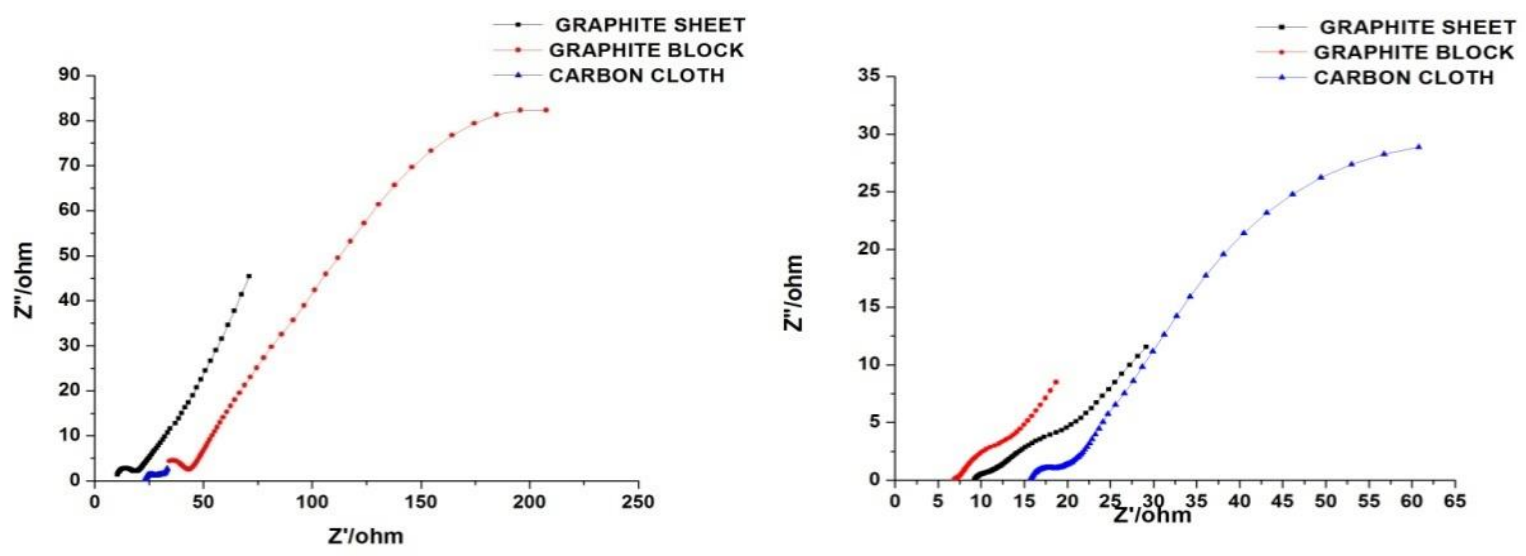

Figure 3: Impedance curves obtained with NMSB and SSA bacteria

The internal resistances were estimated from the Nyquist plots. Using NMSB bacteria, minimum resistance was obtained with graphite sheet i.e. $20.32 \Omega$. Carbon cloth had a minimum internal resistance of $27.68 \Omega$ and with graphite block resistance was found to be $43.11 \Omega$.

Further, using SSA bacteria, minimum resistance was obtained with graphite block i.e. 8.23 $\Omega$. Carbon cloth and graphite sheet had a minimum internal resistance of $18.85 \Omega$ and $11.00 \Omega$ respectively.

\subsection{Cyclic voltammetry (CV)}
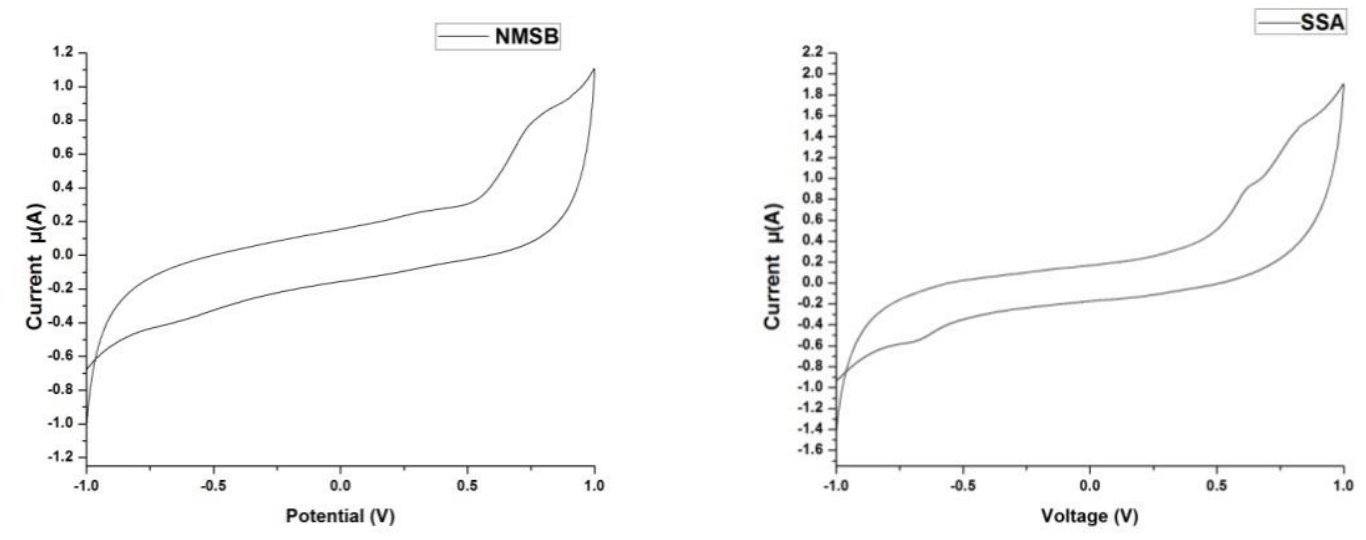

Figure 4: CV obtained with NMSB and SSA bacteria 
A reduction peak was found in the range of $0.5-1 \mathrm{~V}$ in both NMSB and SSA. The peak indicates the electrochemical activity of microorganisms in the anodic compartment. The transfer of electrons to the electrode may be through bacterial outer membrane or with conductive nanowires.

\subsection{Comparison with Shewanella Putrefaciens 8104}

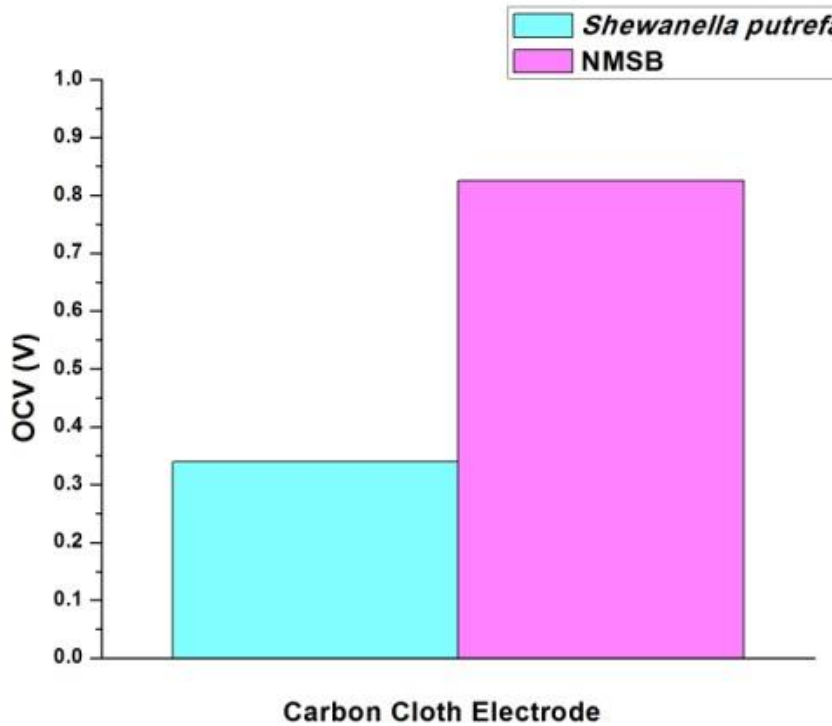

Figure 5: Maximum OCV obtained with NMSB and Shewanella putrefaciens using carbon cloth

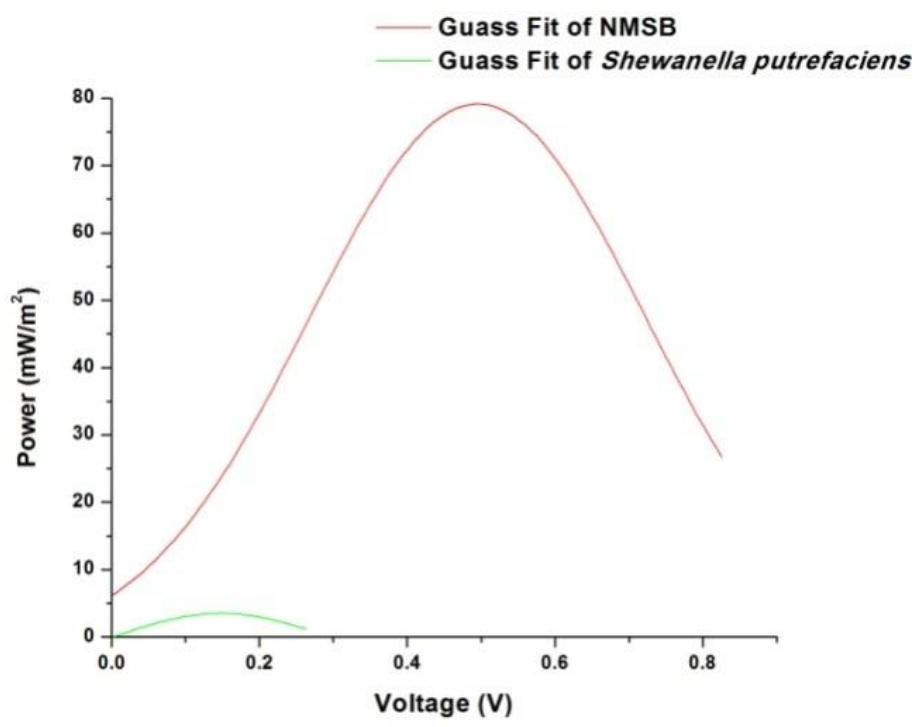

Figure 6: Polarization curves obtained with NMSB and Shewanella putrefaciens using carbon cloth 


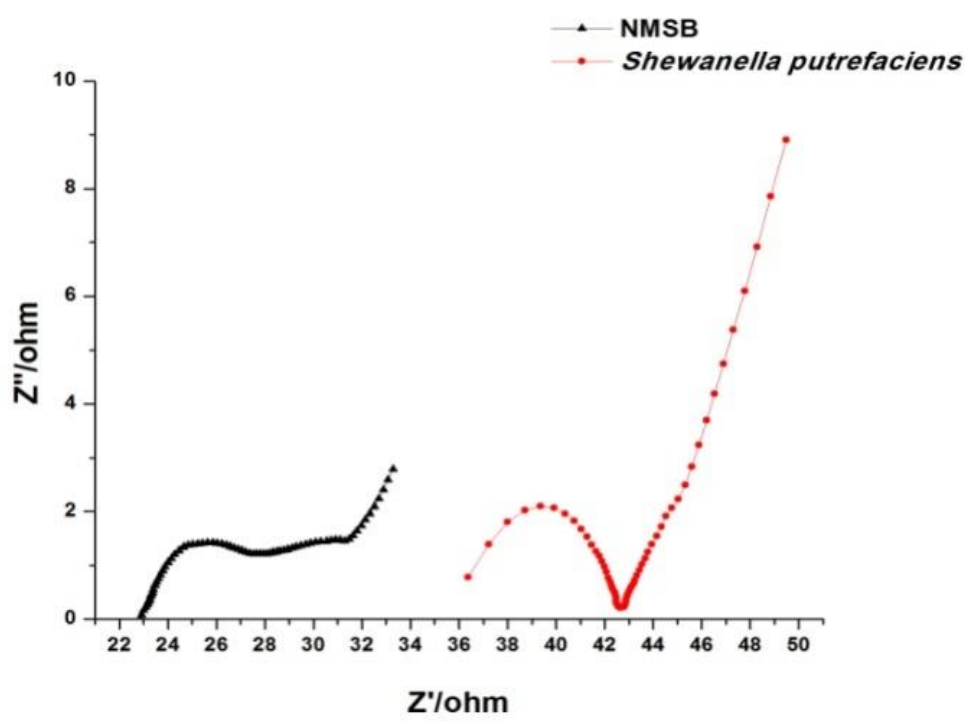

Figure 7: Impedance curves obtained with NMSB and Shewanella putrefaciens using carbon cloth

The performance of MFC with NMSB bacteria that gave better output was compared with Shewanella putrefaciens using carbon cloth as the electrode. The OCV with NMSB bacteria $(0.854 \mathrm{~V})$ was found to be higher than Shewanella putrefaciens, which produced a maximum OCV of $0.339 \mathrm{~V}$. The maximum power density produced using Shewanella putrefaciens was $3.43 \mathrm{~mW} / \mathrm{m}^{2}$ with an internal impedance of $42 \Omega$. This was found to be low when compared with NMSB bacteria which produced a power density of $80 \mathrm{~mW} / \mathrm{m}^{2}$ with an internal impedance of $27.68 \Omega$. Finally, inferring the above studies, the performance of NMSB bacteria was better compared to Shewanella putrefaciens.

\section{Conclusions}

The present study revealed the ability of microorganism for low voltage electricity production in a two chambered MFC. High value of OCV $0.854 \mathrm{~V}$ by using carbon cloth electrode has been obtained. Maximum power density $80 \mathrm{~mW} / \mathrm{m}^{2}$ was achieved using carbon cloth. This is due to the porous structure, larger electrode potential and higher affinity of bacteria towards carbon cloth electrode. Since the output of MFC is as low as $0.2-0.9 \mathrm{~V}$, stacking must be done in order to power the devices.

\section{Acknowledgements}

We thank the Department of Atomic Energy (DAE), Board of Research in Nuclear Sciences (BRNS) (Grant 2013/34/4/BRNS), \& Science and Engineering Research Board (SERB), Government of India for the award of research project.

\section{References}

[1] Logan, B. E. and Regan, J. M., Microbial fuel cells-challenges and applications. Environ. Sci. Technol., 2006, 40, 5172-5180. 
[2] Lee, H.-S.; Parameswaran, P.; Kato-Marcus, A.; Torres, C. I. and Rittmann, B. E., Evaluation of energy-conversion efficiencies in microbial fuel cells (MFCs) utilizing fermentable and nonfermentable substrates. Water Res., 2008, 42, 1501-1510.

[3] Aziz, S.; Memon, A. R.; Shah, S. F.; Soomro, S. A. and Parkash, A., Prototype designing and operational aspects of microbial fuel cell-review paper. Sci.Int.(Lahore)., 2013, 25, 49-56.

[4] Rabaey, K. and Verstraete, W., Microbial fuel cells: novel biotechnology for energy generation. Trends Biotechnol., 2005, 23, 291-298.

[5] Aelterman, P.; Rabaey, K.; Pham, H. T.; Boon, N. and Verstraete, W., Continuous electricity generation at high voltages and currents using stacked microbial fuel cells. Environ. Sci. Technol., 2006, 40, 3388-3394.

[6] Logan, B. E.; Hamelers, B.; Rozendal, R.; Schroder, U.; Keller, J.; Freguia, S.; Aelterman, P.; Verstraete, W. and Rabaey, K., Microbial fuel cells: methodology and technology. Environ. Sci. Technol., 2006, 40, 5181-5192.

[7] Min, B. and Logan, B. E., Continuous electricity generation from domestic wastewater and organic substrates in a flat plate microbial fuel cell. Environ. Sci. Technol., 2004, 38, 5809-5814.

[8] Zhou, M.; Wang, H.; Hassett, D. J. and Gu, T., Recent advances in microbial fuel cells (MFCs) and microbial electrolysis cells (MECs) for wastewater treatment, bioenergy and bioproducts. J. Chem. Technol. Biotechnol., 2013, 88, 508-518.

[9] Jayapriya, J. and Ramamurthy, V., The role of electrode material in capturing power generated in Pseudomonas catalysed fuel cells. Can. J. Chem. Eng., 2014, 92, 610-614.

[10] Bharadwaj, S. K.; Dev Kumar, H. and Babu K, G., A study on the electricity generation from cow dung using microbial fuel cell. J. Biotechnol., 2012, 3, 442-447.

[11] Wang, H.; Park, J.-D. and Ren, Z., Active energy harvesting from microbial fuel cells at the maximum power point without using resistors. Environ. Sci. Technol., 2012, 46, 5247-5252.

[12] Dewan, A.; Beyenal, H. and Lewandowski, Z., Scaling up microbial fuel cells. Environ. Sci. Technol., 2008, 42, 7643-7648.

[13] Kim, H. J.; Park, H. S.; Hyun, M. S.; Chang, I. S.; Kim, M. and Kim, B. H., A mediator-less microbial fuel cell using a metal reducing bacterium, Shewanella putrefaciens. Enzyme Microb. Technol., 2002, 30, 145-152.

\footnotetext{
*Corresponding author.

E-mail address: kglbhat@gmail.com
} 